ARTICLE

Received 17 Dec 2013 | Accepted 16 Apr 2014 | Published 21 May 2014

DOI: $10.1038 /$ ncomms 4900

OPEN

\title{
Physiological and genomic features of highly alkaliphilic hydrogen-utilizing Betaproteobacteria from a continental serpentinizing site
}

Shino Suzuki ${ }^{1}$, J. Gijs Kuenen2,3, Kira Schipper ${ }^{1,3}$, Suzanne van der Velde 2,3, Shun'ichi Ishii', Angela Wu ${ }^{1}$, Dimitry Y. Sorokin ${ }^{3,4}$, Aaron Tenney ${ }^{1}$, XianYing Meng ${ }^{5}$, Penny L. Morrill ${ }^{6}$, Yoichi Kamagata ${ }^{5}$, Gerard Muyzer ${ }^{3,7}$ \& Kenneth H. Nealson ${ }^{1,2}$

Serpentinization, or the aqueous alteration of ultramafic rocks, results in challenging environments for life in continental sites due to the combination of extremely high $\mathrm{pH}$, low salinity and lack of obvious electron acceptors and carbon sources. Nevertheless, certain Betaproteobacteria have been frequently observed in such environments. Here we describe physiological and genomic features of three related Betaproteobacterial strains isolated from highly alkaline $(\mathrm{pH}$ 11.6) serpentinizing springs at The Cedars, California. All three strains are obligate alkaliphiles with an optimum for growth at $\mathrm{pH} 11$ and are capable of autotrophic growth with hydrogen, calcium carbonate and oxygen. The three strains exhibit differences, however, regarding the utilization of organic carbon and electron acceptors. Their global distribution and physiological, genomic and transcriptomic characteristics indicate that the strains are adapted to the alkaline and calcium-rich environments represented by the terrestrial serpentinizing ecosystems. We propose placing these strains in a new genus 'Serpentinomonas'.

\footnotetext{
${ }^{1}$ J. Craig Venter Institute, 4120 Torrey Pines Road, La Jolla, California 92037, USA. ${ }^{2}$ University of Southern California, 835 W. 37th St. SHS 560, Los Angeles, California 90089, USA. ${ }^{3}$ Delft University of Technology, Julianalaan 67, Delft, 2628BC, The Netherlands. ${ }^{4}$ Winogradsky Institute of Microbiology, RAS, Prospect 60-let Octyabrya 7/2, Moscow 117811, Russia. ${ }^{5}$ National Institute of Advanced Industrial Science and Technology, Higashi 1-1-1, Ibaraki 305-8566, Japan. ${ }^{6}$ Memorial University, St John's, Newfoundland, Canada A1B 3X5. ${ }^{7}$ University of Amsterdam, Science Park 904, Amsterdam, 1098XH, The Netherlands. Correspondence and requests for materials should be addressed to S.S. (email: shishii@jcvi.org).
} 
S erpentinization is an aqueous alteration process in which low-silica ultramafic rocks (for example, olivines and pyroxenes) are oxidized and hydrolyzed with water into serpentinite, brucite, magnetite and other minerals. During these reactions, abundant hydrogen gas is produced creating the conditions capable of the abiotic reduction of carbon to produce hydrocarbons ${ }^{1}$. Meanwhile, during the breakdown of clinopyroxene (for example, diopside) in the serpentinization reactions, the high concentration of dissolved $\mathrm{Ca}^{2+}$ in the serpentinizing fluid is accommodated by $\mathrm{OH}^{-}$production due to the absence of a stable $\mathrm{Ca}$ mineral ${ }^{2}$. On exposure to air at terrestrial or seawater, the $\mathrm{Ca}^{2+}$ in the alkaline fluid reacts with dissolved inorganic carbon (DIC) ${ }^{3-5}$ resulting in the precipitation of calcite at the air or seawater/serpentinizing water interfaces. Thus, the fluid issuing from the serpentinite-hosted rocks is generally highly basic, highly reduced, rich in hydrogen, methane and $\mathrm{Ca}^{2+}$, and poor in DIC.

Serpentinization can occur at tectonic plate boundaries where the earth's mantle is uplifted into the crustal zone and exposed to water. Before the differentiation of the lithosphere on early Earth, serpentinization was considered to be widespread in the ocean ${ }^{1}$. On the modern earth, active serpentinization is common in deep ocean environments, including the Mid Atlantic Ridge $^{6}$ and Mariana Forearc ${ }^{7}$, and is known a number of terrestrial sites: for example, California ${ }^{3,8}$, Portugal $^{9}, \mathrm{Canada}^{4}$, Turkey $^{10}$, Oman $^{11}$, Italy ${ }^{12}$, Yugoslavia ${ }^{11}$, Philippines ${ }^{13}$ and the Precambrian Shield in Finland ${ }^{14}$.

'The Cedars', located near the Russian River in northern California within the Franciscan Subduction Complex, is an active terrestrial serpentinizing site $e^{3,8}$. The springs in The Cedars discharge from rocks emplaced during the middle Jurassic $(\sim 170 \mathrm{Ma})^{15}$. The spring waters discharging from The Cedars ultra-mafics have very high $\mathrm{pH}$ values $(\sim 11.6)$, low Eh values $(\sim-500 \mathrm{mV}$ or less) and a relatively high concentration of $\mathrm{Ca}^{2+}(\sim 1 \mathrm{mM})^{3}$. In addition, the spring waters are meteoric in origin, with low concentrations of dissolved organic carbon (DOC), sodium and potassium, and undetectable levels of ammonium, phosphate and electron acceptors (dissolved oxygen, nitrate and sulphate $)^{3}$; a combination that is very challenging for life. For instance, while there is plenty of energy (electron donor) in the form of hydrogen produced by serpentinization, there are very low levels of electron acceptors as well as low levels of protons and sodium to be used for establishing a membrane potential (cation motive force). In addition, DOC is also limited ${ }^{3}$ and the soluble form of carbon dioxide at $\mathrm{pH} 11$ and above is primarily the carbonate ion $\left(\mathrm{CO}_{3}^{2-}\right)$, which is considered to be an unavailable form of DIC for microbes. Therefore, according to present day paradigms of metabolism, it is very difficult to explain how to make a living with regard to performing respiration, carbon assimilation, pumping protons or sodium for energy metabolism and cytoplasm homeostasis in The Cedars springs.

The Cedar springs are fed by either or both of two different hyper alkaline serpentinizing groundwaters (shallow and deep) that have different geochemical properties ${ }^{3}$, and the microbial communities of these springs were found to be strongly correlated with the source groundwater feeding them ${ }^{16}$. While the shallow groundwater communities were similar to those described in other terrestrial serpentinizing sites, the deep groundwater microbial community was distinctly different from any other previously described terrestrial serpentinizing community ${ }^{16}$. The shallow groundwater-fed springs were numerically dominated by microbes related to the genus Hydrogenophaga within Betaproteobacteria ${ }^{16}$. Furthermore, alkaline fluid from other terrestrial serpentine-hosted ecosystems also contained abundant Hydrogenophaga-related microbes ${ }^{17-20}$. Therefore, these microbes appear to be well adapted to geochemical settings occurring at the continental serpentinizing sites, distinguishing them from other cultivated Hydrogenophaga strains $^{21,22}$, none of which are alkaliphilic.

Here we report the isolation and characterization of three different alkaliphilic strains (A1, B1 and H1) that are phylogenetically close to members of the genera Hydrogenophaga ${ }^{21}$ and Malikia ${ }^{23}$ from Barnes spring complex (BSC) in The Cedars ${ }^{3,16}$. We examine the three strains from geobiological, physiological, genomic, comparative genomic and environmental transcriptomic perspectives with a focus on understanding the ecophysiological properties; that is, how the microbes are environmentally distributed and how their metabolic activities potentially interact with the geochemistries of their environments. The isolated strains appear to be highly adapted to the long-lasting, very harsh geochemical conditions present in serpentinite-hosted terrestrial ecosystems.

\section{Results}

Isolation of strains A1, B1 and H1. Strains A1 and B1 were isolated from Barnes Spring 1 (BS1) while strain H1 was isolated from BS5 (Supplementary Fig. 1), which are in the BSC, about $50 \mathrm{~cm}$ apart ${ }^{3}$. Both springs are fed mainly by the discharge of highly alkaline shallow groundwater ${ }^{3}$. The water chemistries of the two springs are similar in terms of the $\mathrm{pH}(\sim 11.5)$, and ion and gas compositions (Supplementary Table 1). DOC and total inorganic carbon in the water in BS5 pool were $20 \mu \mathrm{M}$ and $70 \mu \mathrm{M}$, respectively, while bicarbonate ion levels $\left(\mathrm{HCO}_{3}^{-}\right)$were below the limit of detection $(<2 \mu \mathrm{M})$ (Supplementary Table 1$)^{3}$.

After initial enrichment on glass slides immersed in a mineral medium with hydrogen and acetate, pure colonies were isolated on Cedars Standard Media 1 (CSM1) plates. Single creamy/ opaque colonies formed over a period of 2 weeks cultivation at $16^{\circ} \mathrm{C}$ under gas mixture of $2.6 \% \mathrm{O}_{2}, 50 \% \mathrm{H}_{2}, 9.8 \% \mathrm{~N}_{2}$ and $37.6 \%$ Ar. The phylogenetic tree based on 16S rRNA gene sequences indicated that the three isolated strains were closely related to each other ( $>97.7 \%$ 16S rRNA gene identity) and clustered in family Comamonadaceae, order Burkholderiales, class Betaproteobacteria (Fig. 1). The closest three genera are Hydrogenophaga $^{21}$ Malikia $^{23}$ and Macromonas ${ }^{24}$, and the 16S rRNA gene similarities are summarized in Supplementary Table 2.

Global distribution of related strains. In total 464 environmental $16 \mathrm{~S}$ rRNA clones were recovered from BS5 in the three separate field samplings between 2009 and 2011, and 49\% of the clones were affiliated to the class Betaproteobacteria, which is the numerically dominant class of the microbial community in BS5 (ref. 16), although it should be kept in mind that this method is a semi-quantitative strategy for the community composition assessment. Detailed analyses revealed that 132, 36 and 3 of 292 clones for 16S rRNA gene were identical to those of the strains A1, $\mathrm{H} 1$ and $\mathrm{B} 1$, respectively; thus, the strain $\mathrm{A} 1$ and its close relatives (with $100 \%$ of $16 \mathrm{~S}$ rRNA gene similarity) are the most dominant organism(s) and constitute $\sim 28 \%$ of the bacterial community in BS5 (Fig. 1). Further global distribution of phylotypes associated with strains A1, B1 and $\mathrm{H} 1$ was also examined and summarized in Table 1 . Strains A1, B1 or H1 related microbes ( $>99 \%$ identity in 16S rRNA gene sequences) were detected as one of the dominant phylotypes in most of the studied terrestrial serpentinizing environments including the Cabeço de Vide aquifer (CVA) in Portugal $^{17}$, a Tablelands spring in Canada ${ }^{18}$ and Outokumpu borehole water in Finland $^{20}$ (Table 1). Further analyses revealed that phylotypes related to the isolated strains are abundant not only in actively serpentinizing terrestrial ecosystems, but also in man-made extremely alkaline industrial waste including 


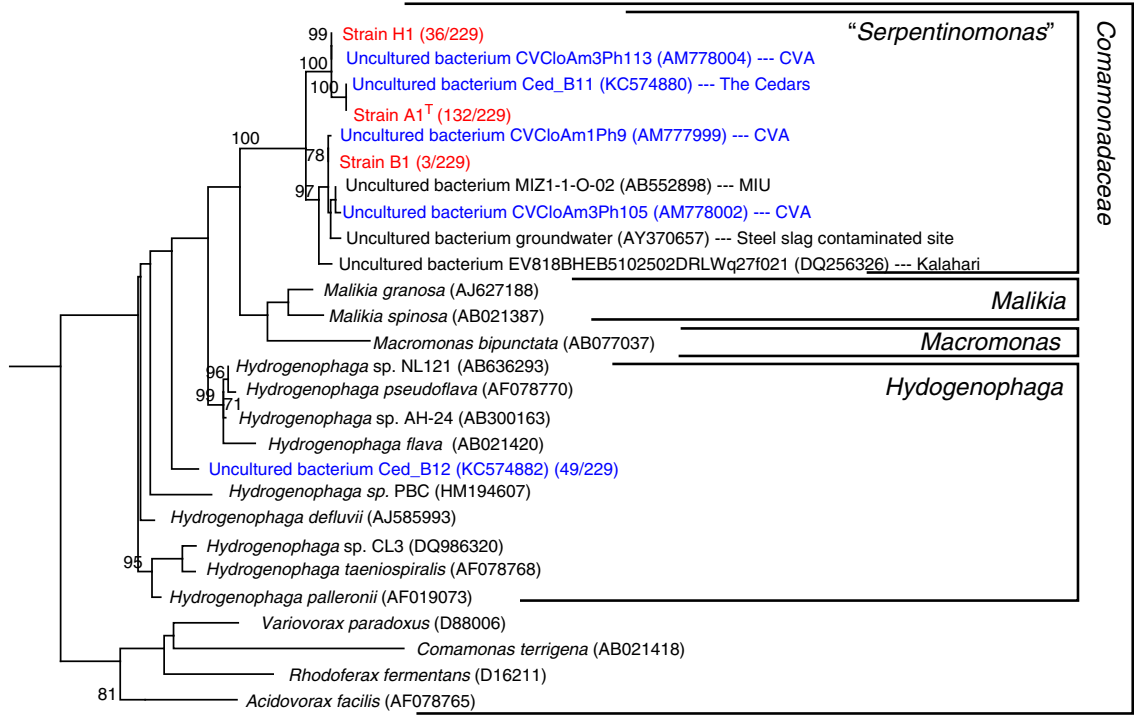

Figure 1 | Phylogenetic relationships among Betaproteobacterial 16S rRNA genes. Tree topologies are supported by bootstrap values for 100 replicates. Red font denotes strains isolated from Barnes spring complex in The Cedars and blue font denotes phylotypes recovered from the continental serpentinization sites including The Cedars. CVA: Cabeço de Vide, MIU: Mizunami Underground Research Laboratory, Kalahari: Kalahari shield.

\begin{tabular}{|c|c|c|c|c|c|c|}
\hline Sampling site & Country & $\begin{array}{l}\text { Occu } \\
\text { pancy } \\
(\%)\end{array}$ & Sample characterization & $\begin{array}{l}\text { The closest } \\
\text { strains to major } \\
\text { phylotypes }\end{array}$ & $\begin{array}{l}\text { Read } \\
\text { length }\end{array}$ & Ref \\
\hline The Cedars (BS5) & USA & $19-61$ & Water issuing from continental active serpentinite site & $A 1$ & Full & 16 \\
\hline Cabeço de Vide (AC3) & Portugal & 20 & Water issuing from continental active serpentinite site & $\mathrm{H} 1$ & Full & 17 \\
\hline Tablelands (WHC2A) & Canada & $24-59$ & Water issuing from continental active serpentinite site & $\mathrm{A} 1 / \mathrm{H} 1^{\ddagger}$ & Short & 18 \\
\hline Outokumpu $100 \mathrm{~m}$ & Finland & 47 & Drilled fluid from ophiolite-palaeoproterozoic formation & $\mathrm{A} 1 / \mathrm{H}^{\frac{1}{+}}$ & Short & 20 \\
\hline Outokumpu $1,000 \mathrm{~m}$ & Finland & 8.5 & Drilled fluid from ophiolite-palaeoproterozoic formation & 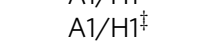 & Short & 20 \\
\hline Outokumpu $1,500 \mathrm{~m}$ & Finland & 4.9 & Drilled fluid from ophiolite-palaeoproterozoic formation & $\mathrm{A} 1 / \mathrm{H} 1^{\ddagger}$ & Short & 20 \\
\hline Mizunami (MIU) & Japan & 15 & Deep groundwater from cretaceous Toki granite & B1 & Full & 27 \\
\hline $\begin{array}{l}\text { Kalahari Shield } \\
\text { (Evander mine) }\end{array}$ & $\begin{array}{l}\text { South } \\
\text { Africa }\end{array}$ & 3 & $\begin{array}{l}\text { Deep ground water from the } 2.0 \text { Ga Bushveld complex } \\
\text { ultramafic/mafic/granite layered intrusive complex }\end{array}$ & B1 & Full & 28 \\
\hline
\end{tabular}

hyperalkaline sediments surrounding a legacy lime (calcium oxide) working site in Buxton, United Kingdom ${ }^{25}$ and microcosm experiments of groundwater from the Lake Calumet area of Chicago where the historic dumping of steel slag has filled in a wetland $\operatorname{area}^{26}$ (Fig. 1, Table 1, Supplementary Table 1). Microbes associated with strains A1, B1 or H1 were also detected in two slightly alkaline deep groundwaters where serpentinization is not suggested (Supplementary Table 1): an ultra-deep granite groundwater in Mizunami ${ }^{27}$, Japan and borehole water from the 2.0 Ga Bushveld complex at the Evander mine in the Kalahari Shield, South Africa ${ }^{28}$ (Fig. 1, Table 1).

In contrast, phylotypes associated with strains $\mathrm{A} 1, \mathrm{~B} 1$ or $\mathrm{H} 1$ were not detected at two continental serpentinizing sites, the Leka ophiolite in Norway ${ }^{19}$ and the Grotto pool spring 1 (GPS1) in
The Cedars, California ${ }^{16}$, nor were they detected in any oceanic serpentinizing sites ${ }^{29-31}$. The geochemistry of the groundwaters from both the Leka ophiolite and GPS1 suggest that they are probably influenced by a marine component despite the fact that they are on land ${ }^{3,32}$ (Supplementary Table 1) for example, the alkaline water discharging from the GPS1 probably contacted the buried marine sediment below The Cedars peridotite. Thus, it appears that these strains are not tolerant of one or more components of the marine system. Overall, the common geochemical features of the sites where the strains A1, B1 and $\mathrm{H} 1$ related microbes were detected are alkaline conditions $(\mathrm{pH}$ $8.2-13)$, relatively high concentrations of calcium $(0.5 \mathrm{mM}-$ $66 \mathrm{mM})$ and a relatively high ratio of $\mathrm{Ca}^{2+} / \mathrm{Na}^{+}(>0.25)$ (Supplementary Table 1). 
General physiological description of the strains. Phase contrast observations revealed that the three isolated strains are motile rods that accumulate polyhydroxybutyrate $(\mathrm{PHB})$ while growing in the presence of acetate (Table 2, Supplementary Fig. $2 \mathrm{~A}-\mathrm{C}$ ) 33 . The strains were unable to grow without the addition of vitamins and very little growth was observed when the cultures were shaken. Also, no growth was observed without the presence of $\mathrm{CaCO}_{3}$. Optimum growth for all the three strains was observed at $26-30{ }^{\circ} \mathrm{C}$ and at $\mathrm{pH} 11$ when they were grown in liquid media (Table 2). The optimum $\mathrm{pH}$ is the highest value for the any prokaryotes reported so far. The $\mathrm{pH}$ range for the growth varied slightly between the three strains. While the 4-[cyclohexylamino]1-butansulphonic acid (CABS)-buffer ensured a stable $\mathrm{pH}$ during growth over a large range of $\mathrm{pH}$ values, it dropped to 11.5 when the initial $\mathrm{pH}$ value of the media was over 12 due to the out of the range buffer action ${ }^{34}$. Since the alkalinity of the medium at $\mathrm{pH} 12$ represents $10 \mathrm{mM}$ hydroxide, the initial $\mathrm{pH}$ is stable and the upper limit of growth can be derived from the initiation of growth at the given $\mathrm{pH}$.

For all three strains, as growth progressed, the crystalline $\mathrm{CaCO}_{3}$ precipitates were transformed into amorphous structures (Supplementary Fig. 3). Observations by confocal laser scanning microscopy revealed that the strains formed aggregates on the $\mathrm{CaCO}_{3}$ precipitates and that the size of the microbe $\mathrm{CaCO}_{3}$ complex became larger as they grew (Supplementary Fig. 4). All three strains grew with a broad range of oxygen $(2.5-20 \%)$ in the headspace, and the growth was inhibited by $\mathrm{NaCl}$ at concentrations above $0.5 \mathrm{gl}^{-1}$.

Utilization of substrates and electron acceptors. The three strains grew heterotrophically with a wide range of carbon substrates including various fatty acids and sugars (Table 2, Supplementary Table 3). In addition, they all grew autotrophically with hydrogen (electron donor), $\mathrm{CaCO}_{3}$ precipitate (carbon

\begin{tabular}{|c|c|c|c|}
\hline & Strain A1 & Strain B1 & Strain H1 \\
\hline Temperature range $\left({ }^{\circ} \mathrm{C}\right)$ & $18-37$ & $18-37$ & $18-37$ \\
\hline Optimum temperature & $26-30$ & 30 & 30 \\
\hline $\mathrm{pH}$ range & $10.0-11.5$ & $9.5-12.5$ & $9-12$ \\
\hline Optimum pH & 11 & 11 & 11 \\
\hline $\mathrm{NaCl}$ range $\left(\mathrm{gl}^{-1}\right)$ & $0-0.5$ & $0-0.5$ & $0-0.5$ \\
\hline Optimum $\mathrm{NaCl}$ & 0 & 0 & 0 \\
\hline Flagella & Polar & Polar & Polar \\
\hline \multicolumn{4}{|l|}{ Autotrophic growth } \\
\hline $\mathrm{H}_{2} / \mathrm{CaCO}_{3} /$ Oxygen & ++ & ++ & ++ \\
\hline \multicolumn{4}{|l|}{ Mixotrophic growth } \\
\hline Acetate & +++ & +++ & +++ \\
\hline Lactate & +++ & +++ & +++ \\
\hline Glucose & + & +++ & +++ \\
\hline Cyclohexane & +++ & \pm & - \\
\hline \multicolumn{4}{|l|}{ Electron acceptor utilization } \\
\hline Oxygen & +++ & +++ & +++ \\
\hline Nitrate & - & +++ & +++ \\
\hline Sulphate & - & - & - \\
\hline Thiosulphate & +++ & - & - \\
\hline \multicolumn{4}{|l|}{ Fermentation } \\
\hline Glucose & - & +++ & +++ \\
\hline
\end{tabular}

source) and oxygen (electron acceptor) (Table 2, Supplementary Fig. 5). Thin sectioning transmission electron microscope (TEM) observation of strain A1 revealed the presence of carboxysomelike structures after 5 days of autotrophic growth (Supplementary Fig. 6A), and abundant PHB accumulations were observed in mixotrophically grown cells with hydrogen, oxygen, $\mathrm{CaCO}_{3}$ and acetate (Supplementary Fig. 6B).

Some differences among the three strains were observed with regard to substrate or electron acceptor utilization, as judged by consumption of substrate(s) or electron acceptor(s), byproduct production and/or cell growth. Strains B1 and H1 (but not A1) grew well via sugar fermentation (Table 2). Strain A1 utilized cyclohexane well as its substrate, which likely originated from the deep groundwater source in The Cedars spring water ${ }^{3}$, while strain B1 and $\mathrm{H} 1$ showed a limited or no growth with cyclohexane, respectively. With regard to electron acceptor utilization, all strains utilized oxygen as an electron acceptor, while only strain A1 utilized thiosulphate with sulphide as one of its products and strains $\mathrm{B} 1$ and $\mathrm{H} 1$ utilized nitrate (Table 2). Strain $\mathrm{H} 1$ also used nitrite as an acceptor, but the product was not measured.

Genomic features of strains A1, B1 and H1. Draft genome sequences of the three strains were determined, and gap-closing efforts were made for strains A1 and B1 (Table 3, Supplementary Fig. 7). The genomes were similar with regard to: (1) size, all were approximately $2.5 \mathrm{Mb}$, which is significantly smaller than those of closely related sequenced strains within class Betaproteobacteria; (2) G + C content; and (3) rRNA gene-copy number. However, strains $\mathrm{B} 1$ and $\mathrm{H} 1$ possess a plasmid $(16 \mathrm{kbp})$, which was not present in strain A1. The plasmid sequences from strains B1 and $\mathrm{H} 1$ are highly conserved with $99.85 \%$ identity, but contain no recognizable metabolism-related genes.

Genome-wide comparisons of strains A1, B1 and H1 (Fig. 2) showed that the three strains, especially strains $\mathrm{Al}$ and $\mathrm{H} 1$, are highly similar in their genomes; however, all three strains were significantly different from Hydrogenophaga sp. strain PBC, the only strain within this genus that has had its genome sequence published (Fig. 2, Table 3$)^{22}$. A metagenomic sequence of the microbial community in spring WHC2B at Tablelands, which was published by Brazelton et al. ${ }^{35}$, showed high similarity with strains A1 and H1 (Fig. 2a,c). Further blastn analyses with higher threshold (lower threshold $>90 \%$ and upper threshold $>95 \%$ ) revealed that the sequences from Tablelands community contain highly conserved strain Al-like genomes in the metagenome (Supplementary Fig. 8A).

In all, $48.5 \%$ of raw reads from the Tablelands metagenome were assigned to the order Burkholderiales where our isolated strains belong ${ }^{35}$ and 9 out of the 10 longest contigs assembled from the Tablelands metagenome showed high similarity with the genome of strain A1 (Supplementary Fig. 9), implying that A1-like microbe(s) are numerically dominant in the Tablelands as well. Detailed comparisons between strain A1 genome and the nine long contigs from Tablelands metagenome indicated that the genome sequences are highly similar except for large indel sequences and/or gene translocations that were observed between the two (Supplementary Fig. 9).

Some gene clusters of strains A1, B1 and $\mathrm{H} 1$ are unique to the genome of each strain, including gene clusters encoding Clustered Regularly Interspaced Short Palindromic Repeats (CRISPRs) and CRISPR-associated proteins (Fig. 3), which are known to be responsible for prokaryotic immunity to phage infection ${ }^{36}$. Detailed comparisons of the CRISPR sequences revealed no similarity between the strains with regards to the numbers of repeats, consensus repeat and spacer sequences. The results may 
Table 3 | Genomic features of strains A1, B1 and H1, and most closely related strains.

\begin{tabular}{|c|c|c|c|c|c|c|c|c|}
\hline & & $\begin{array}{c}\text { Genome } \\
\text { Size (Mb) }\end{array}$ & $\begin{array}{c}\text { Chromosome } \\
\text { Size (Mb) }\end{array}$ & $\begin{array}{c}\text { Plasmid } \\
\text { size (Mb) }\end{array}$ & $\begin{array}{c}\mathbf{G}+\mathbf{C} \\
\text { content (\%) }\end{array}$ & $\begin{array}{c}\text { Total } \\
\text { no. of CDS }\end{array}$ & $\begin{array}{c}\text { No. of rRNA } \\
\text { operons }\end{array}$ & $\begin{array}{c}\text { No. of tRNA } \\
\text { genes }\end{array}$ \\
\hline Strain A1 & Gap_closed & 2.57 & 2.57 & - & 66.6 & 2,374 & 2 & 44 \\
\hline Strain B1 & Gap_closed & 2.62 & 2.60 & 0.016 & 67.7 & 2,413 & 2 & 44 \\
\hline Strain $\mathrm{H} 1$ & Draft & $2.51^{\star}$ & 2.49 & 0.016 & 66.1 & 2,354 & NA & NA \\
\hline Hydrogenophaga sp. PCB & Draft & $5.14^{\star}$ & NA & NA & NA & 4,964 & NA & NA \\
\hline Rhodoferax ferrireducens DSM 15236 & Complete & 4.97 & 4.71 & 0.26 & 59.6 & 4,417 & 2 & 45 \\
\hline Ramlibacter tataouinensis TTB310 & Complete & 4.07 & 4.07 & - & 70 & 3,899 & 1 & 43 \\
\hline Comamonas testosteroni CNB1 & Complete & 5.46 & 5.37 & 0.09 & 61.4 & 4,891 & 3 & 79 \\
\hline
\end{tabular}

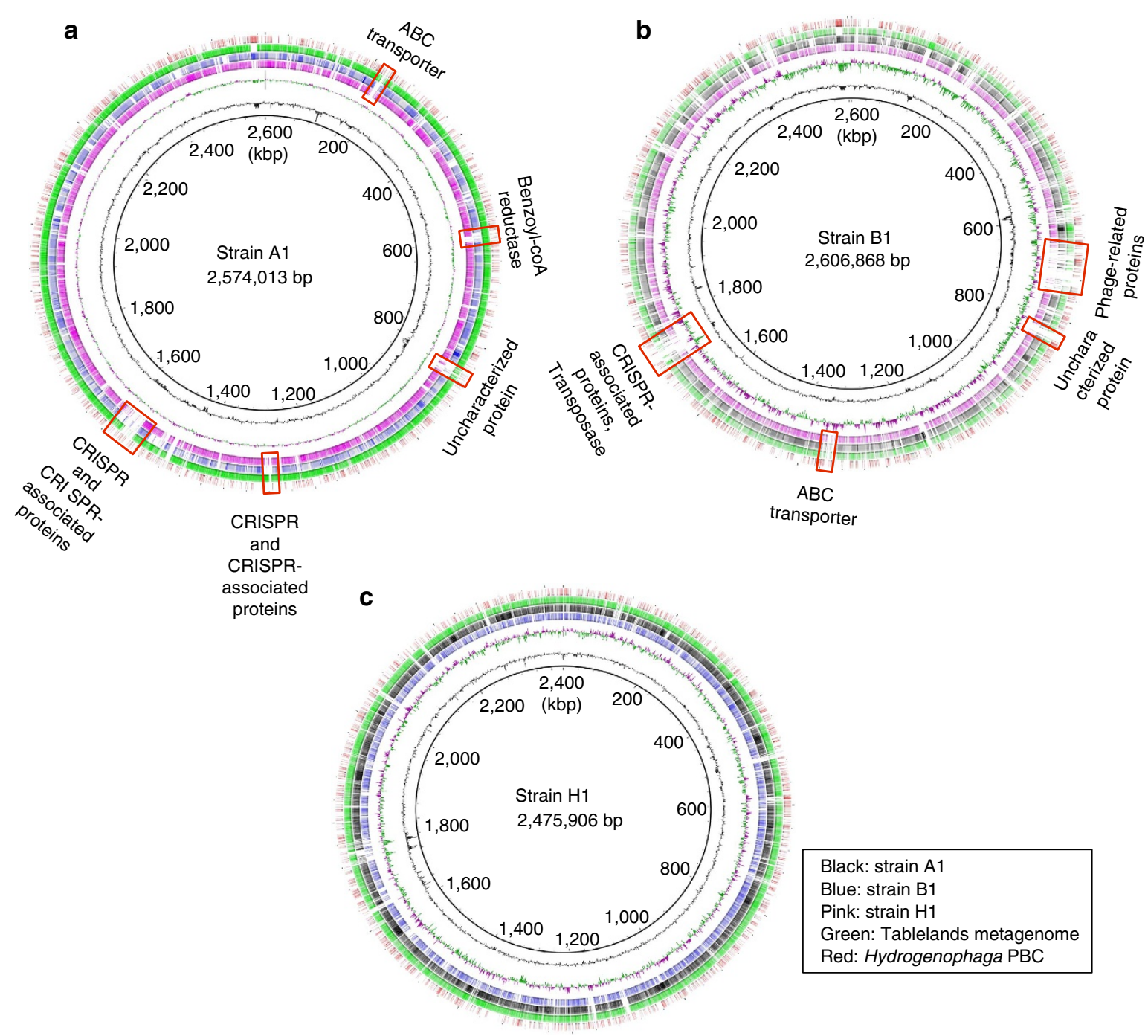

Figure 2 | Circular genome diagrams of the three isolated strains. Genomes for strain A1 (a), B1 (b) and H1 (c) are shown. The inner scales designate the coordinates (in kbp). The first (inner-most) circles show the GC contents and the second circles show the GC-skew. The third and fourth circles show the blastn analysis against the strain A1 (black), strain B1 (blue) and strain $\mathrm{H} 1$ (pink). The fifth and sixth circle show the blastn analysis against the metagenome of Tablelands ${ }^{35}$ and the draft genome of Hydrogenophaga sp. strain PBC 22 . The lower and upper identity threshold in the blastn analysis is $>85$ or $>95$, respectively. The locations of some genes of interest are indicated.

imply a different history of phage interaction for the isolated strains in their respective environments, regardless of the physiological and genomic similarity of the three. While low similarities were observed in CRISPR region between strain A1 and the Tablelands metagenome, several CRISPR-associated proteins showed some similarities. However, all CRISPRassociated proteins from Tablelands metagenome were on short contigs, suggesting that the sequence assemblies of the Tablelands metagenome may be limited in this region due to the repeat sequences contained in CRISPR ${ }^{35}$. 

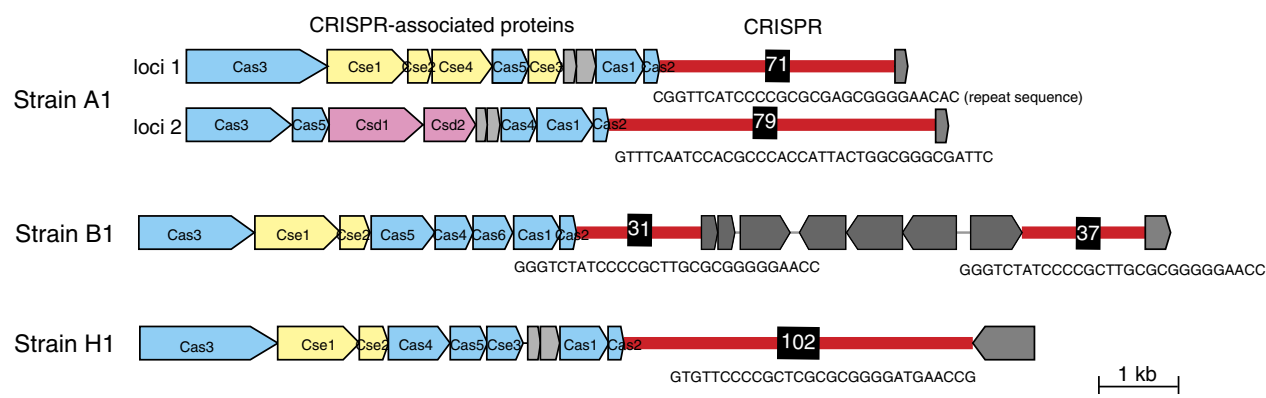

Figure 3 | Comparisons of predicted CRISPR and CRISPR-associated proteins in strains A1, B1 and H1. Coloured boxes represent Cas (blue), Cse (yellow), Csd (pink) and unrelated proteins (gray). Red bars show the consensus repeats and spacer regions and numbers in black box indicate the numbers of repeats.

Metabolic pathways possibly required for inhabiting The Cedars springs. Presence and absence of the gene sets that are assumed to be important for inhabiting this environment within the genomes of three strains were selected and summarized in Fig. 4.

With regard to electron acceptor utilization, all strains have the entire gene complements required for oxygen respiration. In agreement with the physiological analyses, strains $\mathrm{B} 1$ and $\mathrm{H} 1$ have a nitrate reductase gene cluster, while strain A1 lacks it. The genes encoding dissimilatory thiosulphate reductase such as phs genes were not detected in any of the three ${ }^{37}$, although strain A1 was able to reduce thiosulphate and produced sulphide in the physiological analyses.

Well-known electron donors utilized for microbial autotrophic growth are hydrogen and reduced forms of sulphur (sulphide, $\mathrm{S}^{0}$, thiosulphate). Hydrogenase is a key enzyme for autotrophic growth with hydrogen. Strains A1 and B1 have two gene clusters encoding different [NiFe]-hydrogenases while strain $\mathrm{H} 1$ has three. Functional clustering of the resulting [NiFe]-hydrogenase based on the report from Vignais et al. ${ }^{38}$ revealed that all three strains have the hydrogenases clustered into Group $2 \mathrm{~b}$ and $3 \mathrm{~d}$, and only strain $\mathrm{H} 1$ has an additional hydrogenase clustered in Group 1 (Fig. 5). The hydrogenases in Group 1 are known as membrane-bound, respiratory uptake $\mathrm{H}_{2}$ ases capable of supporting growth with $\mathrm{H}_{2}$ as an energy source ${ }^{38}$. However, despite the fact that all three can grow autotrophically, Group1 hydrogenase was detected only in the genome of strain H1. Thus, apparently this type of uptake hydrogenases is not a necessary complement for growth on hydrogen in this taxon. Hydrogenases clustered in Group 2b are known for the involvement in $\mathrm{H}_{2}$ sensing but they are not directly involved in energy production ${ }^{38}$. Meanwhile, hydrogenases clustered in Group 3d are cytoplasmic enzymes and share extensive similarity to the peripheral part of bacterial respiratory Complex 1 . The Group $3 \mathrm{~d}$ hydrogenase is considered to be able to link directly to hydrogen in the cytosol and reduce $\mathrm{NAD}^{+}$to $\mathrm{NADH}$ for supplying the NADH to the carbon fixation ${ }^{38,39}$. In principal, the NADH could also be used as energy source; therefore, the hydrogenase in Group 3d may be highly important in autotrophic growth of the isolated strains.

While partial gene clusters related to sulphur oxidation were detected (only soxYZ) in all three genomes (Fig. 4), other putative sox genes were not seen. Although only strain A1 showed the thiosulphate oxidation accompanied with autotrophic growth, potential genes related to thiosulphate oxidation were not detected in the strain (Table 2).

With regard to inorganic carbon fixation, all three strains have most of the genes and gene clusters encoding enzymes of the Calvin-Benson cycle ${ }^{40}$ while the key genes that are essential for the reverse TCA cycle (Citryl-CoA synthetase) ${ }^{41,42}$ and reductive acetyl-CoA pathway (Acetyl-CoA synthase) ${ }^{43}$ are not present,

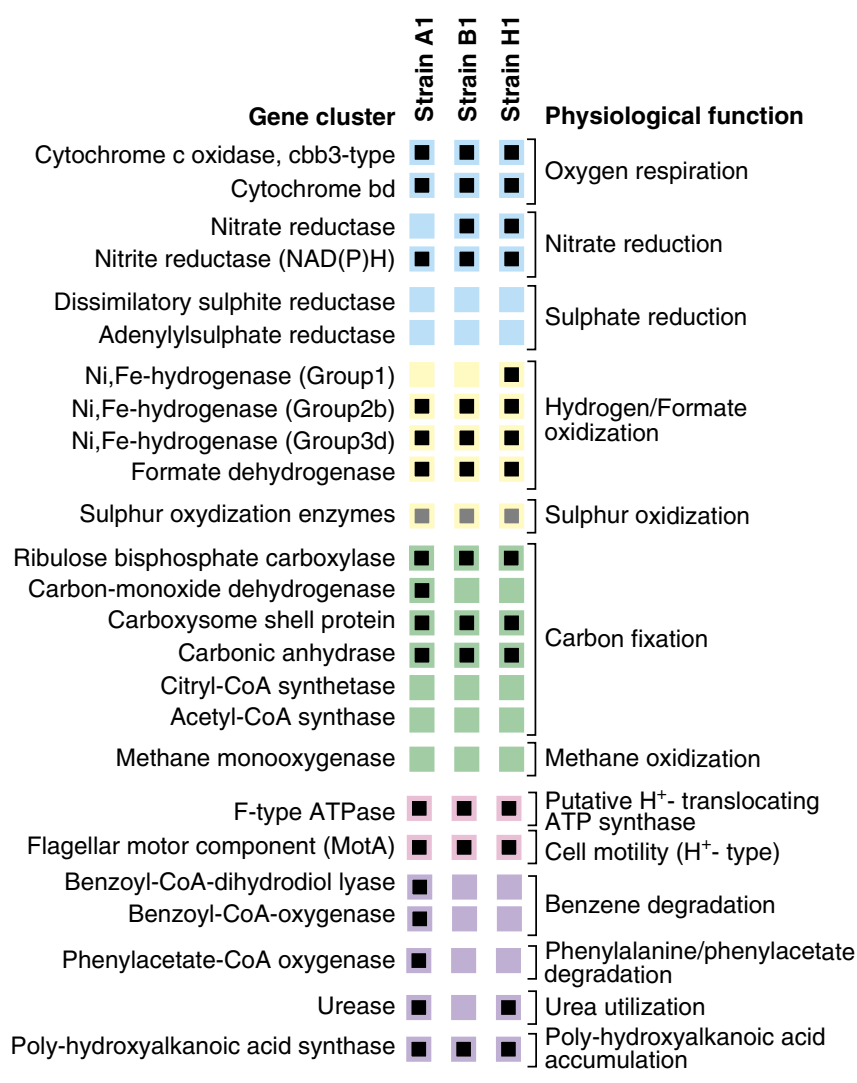

Figure 4 | The presence of selected biosynthetic/catabolic genes or gene clusters in the sequenced strains. Black squares represent the presence of a gene or entire gene cluster within a genome. Grey squares represent partial presence of the gene cluster. Coloured boxes represent genes or gene clusters related to respiration (blue), electron donation (yellow), carbon fixation (green), energy production (pink) and other metabolisms (purple).

suggesting that carbon dioxide fixation is occurring via the CalvinBenson cycle (Fig. 4). In addition, the genes encoding carboxysome shell proteins and a carbonic anhydrase are present in all three genomes, which also support the usage of the Calvin-Benson cycle for carbon fixation ${ }^{44}$. Only strain A1 has putative cox genes (form I) that encode a carbon-monoxide (CO) dehydrogenase $(\mathrm{CODH})^{45,46}$, which was also seen in the Tablelands metagenome. Similar cox genes were detected in Hydrogenophaga pseudoflava that utilizes CO as an energy source ${ }^{47}$, suggesting that strain A1 also may utilize $\mathrm{CO}$ as energy source. No physiological tests of growth on $\mathrm{CO}$ were attempted. 


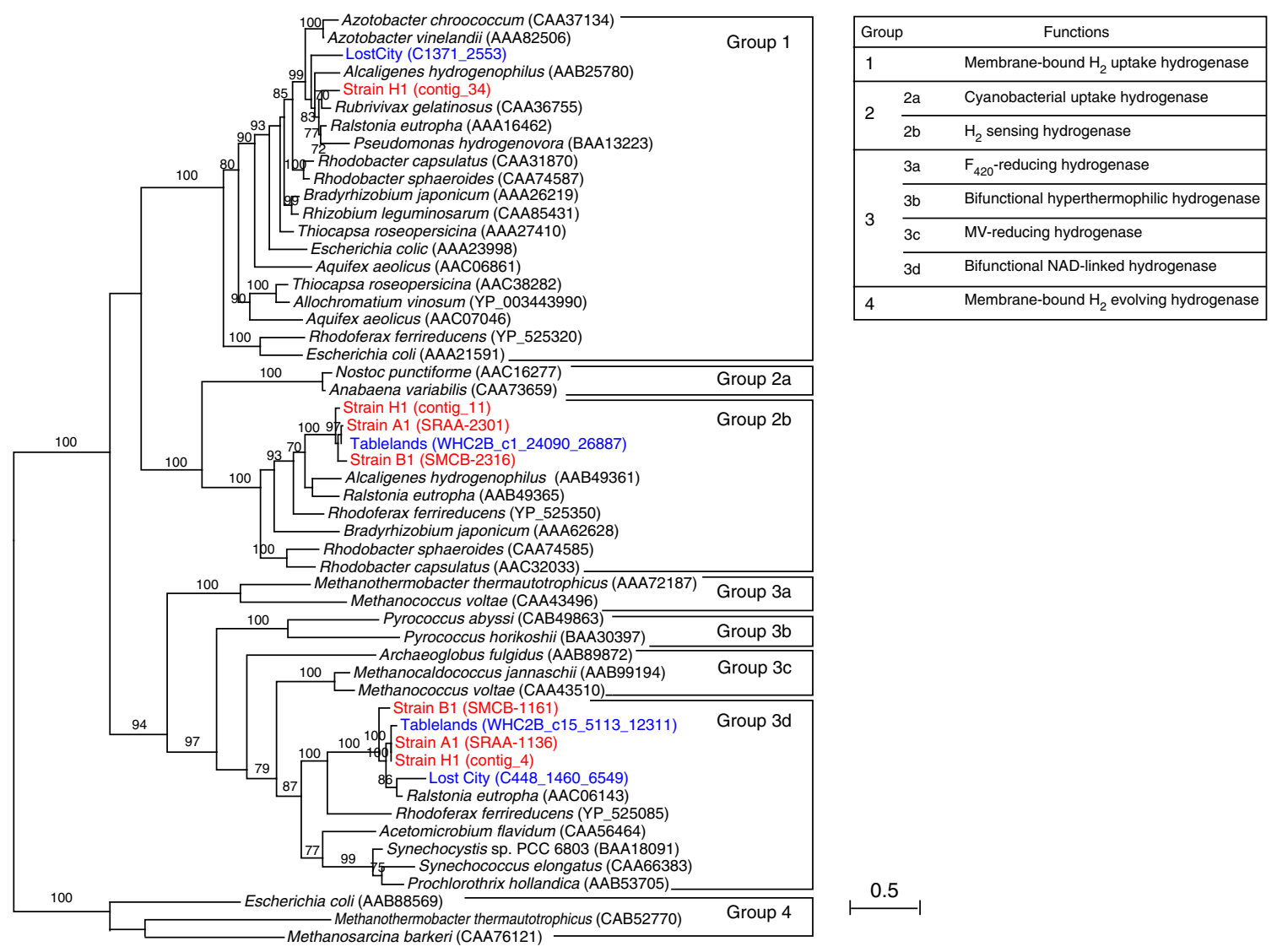

Figure 5 | Phylogenetic diversity of putative [NiFe]-hydrogenases from strains A1, B1 and H1, and from Tablelands metagenomes. Red font denotes the putative hydrogenases from strains $\mathrm{A} 1, \mathrm{~B} 1$ and $\mathrm{H} 1$ and blue font denotes the putative hydrogenases recovered from the Tablelands spring fluid. Group numbers are consistent with the phylogeny reported by Vignais et al. ${ }^{38}$ Maximum-likelihood bootstrap support values $>70$ are shown.

The genes required for carbon fixation were located in a particular region in the genomes or contigs (Supplementary Fig. 10). The sequence comparisons of this region in the genomes between strains $\mathrm{A} 1$ and $\mathrm{B} 1$ as well as contigs from the strain $\mathrm{H} 1$ and the metagenome of Tablelands ${ }^{35}$ indicate that the region is highly conserved. In concert with the genomic similarities between strain $\mathrm{A} 1$ and the Tablelands metagenomic contig noted above, the carbon fixation region also showed the highest similarities among the four compared sequences for these two. The region including $\mathrm{CODH}$ was also presumably an indel sequence, although the contigs from strain $\mathrm{H} 1$ and Tablelands were not long enough for a detailed comparison.

With regard to aromatic organic carbon metabolism, genes encoding benzene degradation and phenylalanine/phenyl-acetate degradation were also detected but only in strain A1. As aromatic compounds and cyclohexane were detected in BS5 water $^{3}$, the feature also may contribute to support the life there.

Although some alkaliphilic microbes are known to utilize sodium ions instead of protons for energy metabolism in alkaline settings ${ }^{48,49}$, the comparisons of the amino-acid sequences of F-type ATPase subunit $c$ indicate that ATPases in the three strains are likely $\mathrm{H}^{+}$-translocating ATP synthase as is commonly observed in aerobic alkaliphilic microbes (Supplementary Fig. 11$)^{50}$. However, in contrast to the well-investigated highly alkaliphilic strain Bacillus pseudofirmus OF4 (ref. 49), the presence of $m o t A^{51}$, the gene encoding the component of the $\mathrm{H}^{+}$-driven bacterial flagellar motor protein, suggests that the flagella-mediated motility of these isolates is also likely driven by a proton gradient: no $\mathrm{Na}^{+}$-driven motor proteins were detected (Fig. 4$)^{52}$. Therefore, regardless of having the highest optimum
$\mathrm{pH}$, the strains presumably utilize a proton motive force (PMF) for energy production.

Expression of autotrophic growth-related genes in strain A1. Autotrophic growth with hydrogen as electron donor and calcium carbonate as carbon source is probably an effective metabolism in an environment with low concentrations of organic carbon and abundant hydrogen and calcite. To confirm the occurrence of autotrophic growth in The Cedars site, gene expression analyses, targeted to the genes presumably required for autotrophic growth, were conducted with the DNA and RNA recovered from the microbial community in BS5 spring water (Fig. 6a), and also RNAs prepared from strain A1 culture grown autotrophically or mixotrophically (Fig. 6b). Strain A1 was not able to grow without $\mathrm{CaCO}_{3}$ and also the growth was significantly inhibited in the absence of hydrogen. Therefore, RNAs from strain Al grown heterotrophically could not be prepared. The primers were designed for detecting the genes from strain A1 specifically, but given the high similarities among the three strains, some of the primers may detect genes from two or three of the strains as well as other related substrains for the in situ gene expression analysis. Thus, the gene expression levels were evaluated by the cDNA/ DNA ratio for the environmental sample, as shown in Fig. 6. Using this approach, all genes targeted in this study were confirmed to be present in the environmental DNAs and expressed to some extent.

The gene encoding Cbb3-type cytochrome oxidase, which is responsible for oxygen respiration, is highly expressed and the gene encoding NADH dehydrogenase, which is a key enzyme to 

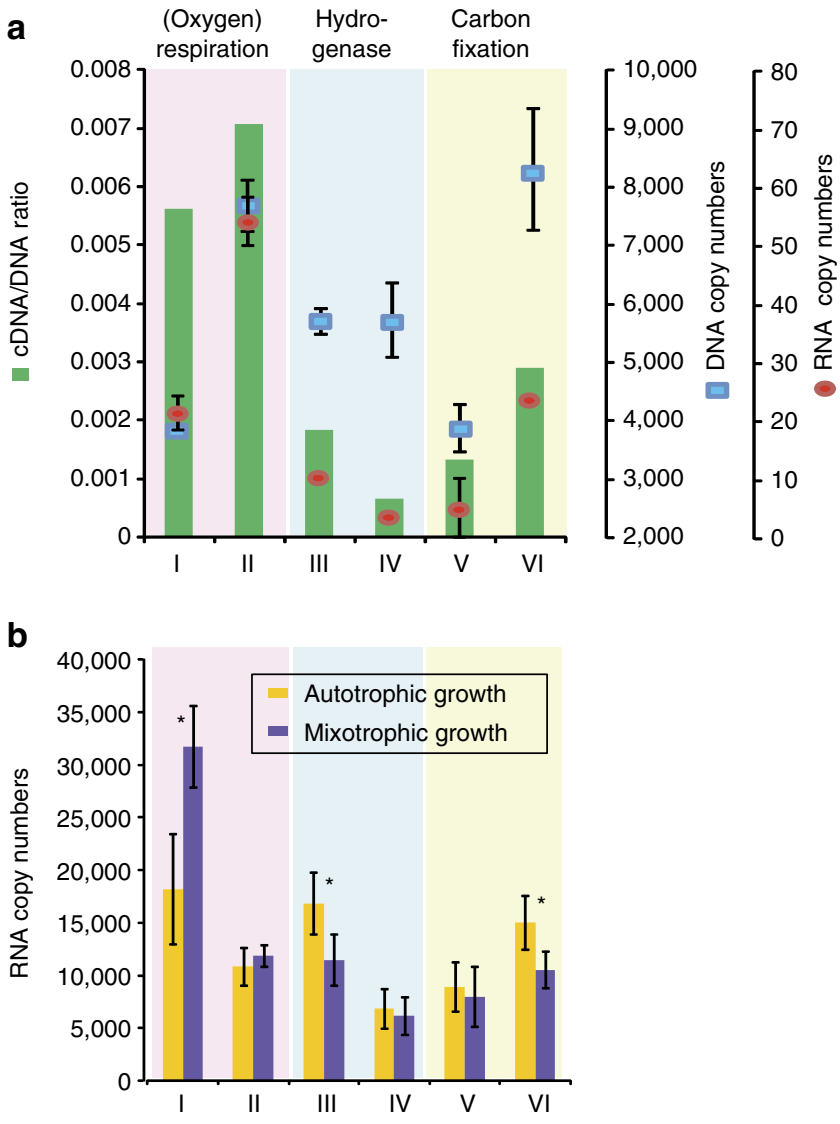

Figure 6 | Gene expression analyses of autotrophic growth-related genes from strain A1. (a) In situ gene expression analysis. Blue squares indicate the copy numbers of each gene in $2.5 \mathrm{ng}$ of DNA recovered from microbial communities in BS5 spring fluid. Red circles indicate the copy numbers of each gene's transcripts in the synthesized cDNA corresponding to $25 \mathrm{pg}$ of RNA recovered from the microbial community in BS5 spring fluid. Green bars indicates cDNA/DNA ratio of each gene. The targeted genes shown as I-VI encode the following proteins: I; Cbb3-type cytochrome oxidase, subunit 1 (SRAA-0853), II; NADH dehydrogenase subunit D (SRAA-0747), III; [NiFe]-hydrogenase in Group 3d (HoxH) (SRAA-1136), IV; [NiFe]-hydrogenase in Group 2 (SRAA-2301), V; Aerobictype carbon monoxide dehydrogenase, large subunit CoxL/CutL homologs (SRAA-2294) and Vl; Ribulose 1,5-bisphosphate carboxylase, large subunit (Rbc L) (SRAA-2317). Bars indicate s.d. ( \pm s.d., $n=3$ ). (b) In vitro gene expression analysis. Yellow and purple bars indicate the copy numbers of each gene's transcripts in the RNAs (cDNA) recovered from strain A1 grown autotrophically (yellow) and heterotrophically (purple). Differences between values in two conditions followed by asterisks are significant $(P<0.01$, Student's t-test) $(n=3)$.

generate proton motive force, is also significantly expressed (Fig. 6a). Although dissolved oxygen was below detection level in the BS5 pool, the $E_{h}$ at the depth of $1,3,10,20$ and $40 \mathrm{~cm}$ below the surface was $-40,-93,-182,-251$ and $-550 \mathrm{mV}$, respectively ${ }^{16}$. Thus, the $\mathrm{E}_{\mathrm{h}}$ gradient suggests that not only is atmospheric $\mathrm{O}_{2}$ dissolving into BS5 pool, but it is also probably being consumed biotically ${ }^{16}$. These results suggest that strain A1 uses oxygen as the electron acceptor and generates energy in the field. These genes were also expressed in the in vitro examination, while the gene encoding Cbb3-type cytochrome oxidase was expressed significantly higher under the mixotrophic growth condition (Fig. 6b).

The gene encoding the hydrogenase clustered in Group $3 \mathrm{~d}$ is highly expressed, while that in Group 2 is poorly expressed in the environment (Fig. 6a). The in vitro study indicates that the Group $3 \mathrm{~d}$ hydrogenase is correlated with the autotrophic growth (Fig. 6b) as predicted by the functional clustering ${ }^{38,39}$. Thus, strain A1 presumably utilizes environmental hydrogen by using the Group 3d hydrogenase.

With regard to the genes related to inorganic carbon fixation, the gene for large subunit of Rubisco $(r b c L)$ was highly expressed in the environment while the gene encoding $\mathrm{CODH}$ (coxL) was poorly expressed (Fig. 6a). The in vitro study indicates that the expression of the $r b c L$ was enhanced significantly during the autotrophic growth while the expression of the coxL was similar during autotrophic or mixotrophic growth. (Fig. 6b). Thus, the Calvin-Benson cycle, which has a Rubisco in the pathway, appears to be method of carbon fixation in the environment.

Proposal for a new genus. The three isolated strains from The Cedars are distinct from the genera Hydrogenophaga, Malikia and Macromonas as indicated in the phylogenetic tree (Fig. 1) and 16S rRNA gene similarity (Supplementary Table 2). In addition, many physiological properties also distinguish them from the previously known genera. Therefore, we propose strains A1, B1 and $\mathrm{H} 1$ as a new genus Serpentinomonas and strain A1 as the type strain of this genus. Generally, in species-level taxonomic comparisons, DNADNA hybridization is known as the most confident way for describing the genetic distance of multiple strains ${ }^{53}$. On the basis of the principal of DNA-DNA hybridization strategy, in silico DNA-DNA hybridization was employed for determining the species level taxonomy of these three (Supplementary Fig. 12). When $80 \%$ of similarity cutoff and $95 \%$ of length cutoff were applied for the mapping, strains A1 and $\mathrm{H} 1$ shared more than $70 \%$ of genome similarity; however, strain B1 shared only around 50\% with the other two strains, suggesting that strains $\mathrm{A} 1$ and $\mathrm{H} 1$ can be considered as one species while strain B1 is different. Thus, we propose three strains isolated from The Cedars springs as a new candidate genus and species Serpentinomonas raichei strain $\mathrm{A} 1^{\mathrm{T}}$ and $\mathrm{H} 1$, and Serpentinomonas mccroryi strain B1, respectively. A formal description of the new taxa will be reported elsewhere.

\section{Discussion}

The Serpentinomonas strains described here are obligatory alkaliphilic and facultative hydrogen-utilizing bacteria. Closely related strains were numerically dominant microbes in various terrestrial active serpentinizing sites around the globe (Table 1). Thus, it would appear that these strains are very relevant to understanding the interactions between the geochemistry of terrestrial serpentinization sites and the microbes that inhabit them.

Abiotically released $\mathrm{Ca}^{2+}$ in a highly alkaline environment reacts rapidly with DIC to form insoluble calcium carbonate (Supplementary Fig. 1) ${ }^{3,9}$. Under such limiting conditions of DIC, Serpentinomonas strains utilize $\mathrm{CaCO}_{3}$ for carbon fixation, coupled with hydrogen oxidation at high $\mathrm{pH}$. Thus, the $\mathrm{Ca}^{2+}$ released in the alkaline water appears to be a great carbontrapping mechanism for the Serpentinomonas microbes. To our knowledge, no microbe capable of fixing carbon at that high $\mathrm{pH}$ using calcium carbonate as the source of inorganic carbon has been reported. The possible explanation of the phenomenon for the utilization of $\mathrm{CaCO}_{3}$ at $\mathrm{pH} 11$ is that the strains aggregate on $\mathrm{CaCO}_{3}$ and may decrease the $\mathrm{pH}$ in the microenvironment surrounding them by generating a proton gradient, (Supplementary Fig. 4), thus converting the soluble carbonate released from the calcite to produce bicarbonate for immediate carbon uptake. An alternative explanation is that the Serpentinomonas strains may have extremely high affinity bicarbonate transporter(s), and these strains closely attach to 
$\mathrm{CaCO}_{3}$ and may locally increase the solubility of calcium carbonate. In either case, the fixed carbon from $\mathrm{CaCO}_{3}$ by the strains could affect to the other community members' metabolisms by providing the organic carbons.

In addition to the autotrophic growth strategy, Serpentinomonas strains have diverse metabolic abilities in terms of organic carbon compound and electron acceptor utilization (Table 2, Supplementary Table 3). The 'edge of life' conditions with regard to highly limiting electron acceptors and carbon sources during evolution may have stimulated an opportunistic life style with regard to available substrates and thus may have facilitated the acquisition of the diverse metabolic capabilities. In addition, varying CRISPR immune components in each strain indicate that the histories of virus (phage) infection are different ${ }^{36}$ (Fig. 3). Because of the harsh environment, microbial competitors of these strains are probably not abundant, and eukaryotic predators are virtually absent ${ }^{16}$, but the virus infection may be an important component for the genetic exchange between microbes in The Cedars springs.

Given their small genome size in comparison with taxonomically similar microbes living in less challenging environments, it appears that many excess genes have been lost via genome streamlining ${ }^{54-56}$. An alternative hypothesis is that these microbes are the 'precursors' of other 'more modern' microbes, which have achieved their genomes by accretion of new genes ${ }^{56}$. Although the organisms are clustered into the family Comamonadaceae, the latter hypothesis might be more compatible with the observation that genomically close strains are seen in globally separated ecosystems and also highly related strains are seen in present day serpentinization of Precambrian shield and other younger serpentinite ecosystems. In such harsh environments, with few predators, and consistently harsh and relatively stable conditions, there may be little advantage to change and/or diverge.

Environmental and in vitro gene expression profiles indicate the occurrence of autotrophic growth with hydrogen, oxygen and carbon dioxide in The Cedars spring. On the basis of the genomic and transcriptomic analyses in this study, we assumed that Serpentinomonas strains utilize cytoplasmic hydrogenase (Group 3d), which can link hydrogen directly and reduce $\mathrm{NAD}^{+}$ to $\mathrm{NADH}$, for the hydrogen oxidation accompanied with the energy production. Since this enzyme normally links to Complex I of the respiratory chain, this route would potentially yield more energy than the (periplasmic) Group I hydrogenase, which links to the Q-pool of the respiratory chain ${ }^{57}$. In addition, in the highly alkaline and hydrogen-rich environment, hydrogen oxidation in the cytosol may be more effective with regard to the energy production. The physiological functions of the different hydrogenases must be further analysed since the hydrogenases obviously are very important in creating a proton motive force and cytoplasm homeostasis at this high $\mathrm{pH}$.

One of the mysteries of the Serpentinomonas strains relates to their energy metabolism and homeostasis. The study of an alkaliphilic gram-positive bacteria, B. pseudofirmus OF4, proved that the strain developed several strategies to adapt $\mathrm{pH}>10$ including alkaliphile-specific features of the ATP synthase (for example, changes at the c-ring's ion binding site as well as its size and stoichiometry $)^{58}$ and also delocalized gradients near the membrane surface and proton transfers to ATP synthases via membrane-associated microcircuits between the proton pumping complexes and synthases ${ }^{49}$. Since the Serpentinomonas strains are gram-negative bacteria, grow well only above $\mathrm{pH} 10.5$ and the important protein motif in c-ring of ATPase (AxAxAxA) in strain OF4 (ref. 58) was not detected in that of Serpentinomonas strains, the Serpentinomonas strains may have a different strategy of adaptation to the calcium-rich and sodiumpoor ultrabasic environment.
In conclusion, the 'edges of life' conditions found at continental serpentinizing environments appear to have selected for quite similar Serpentinomonas strains. In this study, we revealed various aspects of Serpentinomonas strains' characteristics, especially focused on the ecophysiological perspective. Through this study, further questions and hypotheses have been raised concerning the microbial evolution and energy metabolism of Serpentinomonas strains. Answering those must provide further new insights into microbial life on modern or perhaps early Earth.

\section{Methods}

Sampling sites and sample collections. Water samples for microbial isolations were collected from BS1 and BS5 (BSC: elevation $282 \mathrm{~m}, \mathrm{~N}: 38^{\circ} 37.282^{\prime}$, W: $123^{\circ} 7.987^{\prime}$ ) within The Cedars ${ }^{3}$ and used for various liquid enrichments in basal media supplemented with or without organic substrates (see 'Medium

composition'). Since no visible turbidity developed, pre-autoclaved glass slides or glass beads $(0.11 \mathrm{~mm}$ diameter ballotini beads) were incubated in situ in the BS1 pool, just above the entry of the spring in the pool at $\mathrm{E}_{\mathrm{H}}$ of around -250 to $350 \mathrm{mV}$ in July 2005. After 1-2 weeks, microscopic inspection showed profuse growth on the slides or beads. The slides and beads were used for enrichments in the laboratory (see below). BS5 water was collected in October 2010 and directly used for enrichments.

Cell samples for DNA and RNA analyses were pumped and collected from the water in BS5 pool with Tygon Chemical Tubing (Masterflex) equipped with PFA In-Line filter holders (Advantec) in 2011 (ref. 16). The $0.22-\mu \mathrm{m}$ in-line filters (Millipore) were used for microbial cell collection. The water flow rate was $\sim 150 \mathrm{ml} \mathrm{min}^{-1}$ and the filter was exchanged every $30 \mathrm{~min}$. The filtered cells were frozen immediately with dry ice at the sampling site and kept at dry ice temperature during the transportation. Final water volume filtered for the DNA and RNA extraction was $\sim 1501$.

Bacterial isolation. Water samples, preincubated slides or beads were used as inoculum for further liquid enrichments in the laboratory in basal (minerals + vitamins) medium ( $\mathrm{pH}$ 9.5-11.5) supplemented with $30 \%$ (v/v) prefiltered BS1 or BS5 water and incubated at $16-18^{\circ} \mathrm{C}$ with and without various organic substrates in an atmosphere of $\mathrm{H}_{2}(0.25-0.50 \mathrm{~atm}), \mathrm{CH}_{4}(0.0-0.25 \mathrm{~atm}), \mathrm{O}_{2}(0.05 \mathrm{~atm})$ and $\mathrm{N}_{2}$ or Ar $(0.45 \mathrm{~atm})$, with immersed ballotini beads or a glass slide as support.

After 1-2 weeks, the enrichments in the liquid or on the glass surface were streaked on basal agar media with $2 \mathrm{mM}$ acetate for the development of colonies in the same gas mixture at $16-18{ }^{\circ} \mathrm{C}$. Slightly different creamy/opaque colonies obtained from pool BS1 were restreaked at least five times to obtain pure cultures and labelled strain $\mathrm{A} 1$ and $\mathrm{B} 1$. After suspension, the strains were stored in glycerol $(20 \% \mathrm{v} / \mathrm{v})$ at $-80^{\circ} \mathrm{C}$, in 2005 . Strains $\mathrm{A} 1$ and B1 were revived from the stored colonies in 2010 for physiological tests and further cultivated in an atmosphere of $\mathrm{O}_{2} / \mathrm{H}_{2} / \mathrm{N}_{2} / \mathrm{Ar}$ 2.6:50:9.8:37.6 by volume ( $1 \mathrm{~atm})$ at $16^{\circ} \mathrm{C}$. If $\mathrm{H}_{2}$ was not desired in the medium, it was replaced by $\mathrm{N}_{2}$ or Ar.

BS5 pool water collected in 2010 was directly used for enrichments in the laboratory at $16-18^{\circ} \mathrm{C}$ on basal medium supplemented with $30 \%$ prefiltered BS5 water under the same gas atmosphere. The liquid medium, supplemented with $4 \mathrm{mM}$ acetate, contained a glass slide to promote visible attached growth. From this enrichment strain $\mathrm{H} 1$ was isolated in pure culture, as described for strains A1 and $\mathrm{B} 1$, on basal agar medium with acetate under $\mathrm{O}_{2} / \mathrm{H}_{2} / \mathrm{N}_{2} / \mathrm{Ar} 2.6: 50: 9.8: 37.6$ by volume (1 atm)

Pure cultures were grown at $16^{\circ} \mathrm{C}$ in liquid basal media with acetate, concentrated by (aseptic) centrifugation and then stored in glycerol $(20 \% \mathrm{v} / \mathrm{v})$ at $-80^{\circ} \mathrm{C}$.

Medium composition. Media consisted of 'basal' Cedars Standard Medium 1 (CSM1) supplemented with a large range of organic substrates at $0.5-4 \mathrm{mM}$ concentrations adjusted to various $\mathrm{pH}$. Acetate was used at 2-4 mM. The CSM1 contained $0.05 \mathrm{mM} \mathrm{Na}_{2} \mathrm{SO}_{4}, 0.378 \mathrm{mM} \mathrm{NH}_{4} \mathrm{Cl}, 0.05 \mathrm{mM} \mathrm{MgCl}_{2}, 0.06-0.115 \mathrm{mM}$ $\mathrm{K}_{2} \mathrm{HPO}_{4}$ (matching the 2 or $4 \mathrm{mM}$ acetate concentration used), $2.00 \mathrm{mM} \mathrm{CaCO}$ (as suspension), $10 \mathrm{mM} \mathrm{CABS}$ or $\mathrm{Na}_{2} \mathrm{CO}_{3} / \mathrm{NaHCO}_{3}, 10 \mathrm{mll}^{-1}$ of ATCC Trace Mineral Supplement and $10 \mathrm{mll}^{-1}$ of ATCC Vitamin Solution (or self-prepared basic vitamin solution, with concentrations identical to those in ATCC Vitamin Solution but without $\mathrm{KH}_{2} \mathrm{PO}_{4}$ ). The $\mathrm{pH}$ of the CSM1 was adjusted by using $\mathrm{NaOH}$. For optimum growth, the $\mathrm{pH}$ was adjusted to $10.5-11.2$ and the temperature was $16-18^{\circ} \mathrm{C}$. Since the cell growth could not be monitored by the optical density due to the low cell density as well as the precipitate of calcium carbonate, the cells were stained with SYBR Green I and collected on black filters and monitored under fluorescent microscopy, or monitored by directly placing the glass slides under the phase-contrast microscope.

Pure colonies were isolated on CSM1 plates supplemented with 2-4 mM acetate, with $2 \%$ prewashed Noble (Difco) or Korean (Daishin) agar (Brunschwig Chemie, Amsterdam, NL). Small (0.2-1 mm) creamy/opaque colonies formed over a period of 2 weeks cultivation at $16^{\circ} \mathrm{C}$ under a gas mixture of $\mathrm{O}_{2} / \mathrm{H}_{2} / \mathrm{N}_{2} / \mathrm{Ar}$ 2.6:50:9.8:37.6 by volume ( $1 \mathrm{~atm})$. Once the temperature optimum and $\mathrm{pH}$ 
optimum was determined, cultures were routinely grown at $28^{\circ} \mathrm{C}$ and $\mathrm{pH} 10.8-$ 11.2. 3-(Cyclohexylamino)-1-propanesulphonic acid (CAPS) (Sigma) was used instead of CABS in a gas mixture of $\mathrm{O}_{2} / \mathrm{H}_{2} / \mathrm{N}_{2}$ or $\mathrm{Ar}$ 2.6:50:47.4 by volume ( $1 \mathrm{~atm}$ ).

Although initial enrichments and isolations were performed in the condition described above, the cultivation condition was optimized for the further physiological examinations. The basal liquid media for the physiological analysis (Cedars Standard Media 2 (CSM2)) was composed with $0.1 \mathrm{mM} \mathrm{Na}_{2} \mathrm{SO}_{4}$, $0.755 \mathrm{mM} \mathrm{NH}_{4} \mathrm{Cl}, 0.1 \mathrm{mM} \mathrm{MgCl}_{2}, 0.23 \mathrm{mM} \mathrm{K}_{2} \mathrm{HPO}_{4}, 20.0 \mathrm{mM} \mathrm{CaCO}_{3}$ (as suspension), $15 \mathrm{mM}$ CAPS and self-prepared Trace Mineral and Vitamin Solution ${ }^{59}$. The portion for the liquid and gas phase is approximately $35: 65$. The gas composition is $\mathrm{H}_{2} / \mathrm{N}_{2} / \mathrm{Air}$ 35:35:30, the temperature for the cultivations is at $30{ }^{\circ} \mathrm{C}$ and $4 \mathrm{mM}$ of sodium acetate was added unless otherwise noted.

Physiological characterization. The optimum and range of $\mathrm{pH}$, temperature and sodium chloride concentrations for the growth were evaluated by the increase in cell numbers and consumption of acetate. For electron donor or carbon source examinations, the $4 \mathrm{mM}$ of substrates listed in Supplementary Table 3 was added instead of $4 \mathrm{mM}$ of sodium acetate. $\mathrm{N}_{2} / \mathrm{Air}=7: 3$ was used as the gas phase for the electron donor examination while the gas phase contained $\mathrm{H}_{2}$ (see above) was used for the carbon source examination. The growth was confirmed by the increase in cell numbers compared with those of the controls. In addition, the consumptions of acetate, propionate, butyrate, lactate hydrogen were confirmed. Pyruvate and formate were not accurately measured in our system due to the instability of compounds. The growth with glucose, glutamate, glycerol and cyclohexane was evaluated only from the increase in cell numbers.

In the examinations of electron acceptor utilizations, $\mathrm{N}_{2} / \mathrm{H}_{2}=5: 5$ (except for the oxygen utilization) was used for the gas composition and the electron acceptor availability was evaluated the increase of cell number and consumption of acetate. In addition, the reduction of the nitrate, sulphate, thiosulphate and iron was evaluated by nitrite, sulphide or iron (II) productions. Nitrite, sulphide and iron (II) were detected with Griess ${ }^{60}$, methylene blue ${ }^{61}$ or ferrozine methods ${ }^{62}$, respectively.

HPLC and gas chromatography. Volatile fatty acid (VFA) (acetate, propionate, butyrate, lactate) concentrations in the media were measured using a HPLC machine equipped with a multiple wavelength detector (Agilent 1200 series) and a reverse phase C18 column ${ }^{59}$ (Epic Polar, ES Industries or Synergi $4 \mu \mathrm{m}$ Hydro-RP $80 \AA ̊$, Phenomenex). The eluant was $50 \mathrm{mM}$ phosphoric acid ( $\mathrm{pH}$ 1.87) for Epic Polar and $0.5 \mathrm{mM}$ sulphuric acid ( $\mathrm{pH}$ 2.61) for Synergi $4 \mu \mathrm{m}$ Hydro-RP $80 \AA$ at a flow rate of $1.0 \mathrm{ml} \mathrm{min}^{-1}$. Acetate, propionate, butyrate and lactate were identified and determined based on known standards (detection limit was $>0.1 \mathrm{mM}$ ).

Hydrogen gas concentration was measured by GC (CP-3800, Varian) using a Fused Silica Molsieve 5A column (CP7537, Varian). Hydrogen peaks and concentrations were identified with the comparison with the standard and the standard curve prepared with pure hydrogen.

Microscopy. For both confocal laser scanning microscopy (confocal microscopy) and TEM, bacterial cells were grown autotrophically with $\mathrm{H}_{2}, \mathrm{O}_{2}$ and $\mathrm{CaCO}_{3}$ or mixtrophically with $\mathrm{H}_{2}, \mathrm{O}_{2}$, acetate and $\mathrm{CaCO}_{3}$. Confocal microscopic observation was made for the bacterial cells grown for 3 days under the condition described above. The samples were collected by needle from the bottle with bacterial culture. The collected cells were stained with SYBR green I (Life Technologies) and observed directly under confocal microscopy. For TEM observation, bacterial cells grown for 5 days were harvested by centrifugation, fixed with $2.5 \%$ glutaraldehyde in $0.1 \mathrm{M}$ sodium phosphate buffer ( $\mathrm{pH} 7.4)$ at $4{ }^{\circ} \mathrm{C}$ for $5 \mathrm{~h}$ and then postfixed with $2 \%$ osmium tetroxide for $90 \mathrm{~min}$ at $4{ }^{\circ} \mathrm{C}$. The fixed cells were embedded in $1.5 \%$ agarose before dehydration with a graded ethanol series. The dehydrated specimens were embedded in Epon812 resin. Ultrathin sections of the samples were prepared with a Reichert-Nissei ultramicrotome (Ultracut-N), mounted on copper grids and stained with $1 \%$ uranyl acetate and $0.3 \%$ lead citrate. Images of sections were obtained by using a Hitachi model H-7600 transmission electron microscope operating at $80 \mathrm{kV}$.

Sequencing and sequence assembling. DNAs from Serpentinomonas strains for the genomic sequencing were extracted using the MObio PowerBiofilm DNA Isolation Kit (MObio). The prepared DNA was used for library construction for Illumina Hiseq. Paired-end libraries were prepared using Bioo Scientific NEXTflex Library Prep Reagents for Illumina kit and protocol, with Bioo Scientific NEXTflex PCR-Free Barcoded adapters. Cluster generation and sequencing were conducted by employing the 101-bp read length option. Paired-end sequencing approaches were conducted by Illumina's standard protocol. Total reads generated from the sequencing were $3,857,324,4,385,866$ and $5,253,809$ for strain A1, B1 or H1, respectively. The de novo assembly of genomic sequences was primary conducted using the Velvet assembler. The assembled contigs were compared with those from CLC assembly (Version 6.0.3) and the contig for each strain was finalized. The assembled stats are shown in Supplementary Table 4 . The contig gaps in strains A1 and B1 genomes were closed by PCR-based primer walking. As for strain H1, over $300 \mathrm{bp}$ of contigs ( 93 contigs for the chromosome and 1 contig for the plasmid) were applied for the further genomic analyses.
Environmental DNA and RNA extraction. Several chemical and mechanical cell disrupting methods were examined for effectively extracting total nucleic acids from the microbial cells inhabiting in The Cedars highly alkaline fluid, and a modified MObio PowerBiofilm RNA Isolation Kit (MObio) was selected to achieve the highest yield of total nucleotide. The standard MObioRNA extraction method was followed with modifications described here. First, the frozen cells on the filter were directly added to the power beads containing Solution BFR $1 / \beta$-mercaptoethanol. After inhibitor removal steps, we skipped the DNA removal process and moved to the washing step ${ }^{63}$. Extracted total nucleic acids were separated using the AllPrep DNA/RNA Mini Kit (Qiagen). RNA from strain A1 was also prepared using MObio PowerBiofilm RNA Isolation Kit according to the manufacturer's instruction.

Gene expression analyses. cDNAs were synthesized from the prepared RNAs using SuperScript VILO cDNA Synthesis Kit (Life technologies). Twenty nanograms of total RNAs from the environmental cell samples and $10 \mathrm{ng}$ of total RNAs prepared from the $250 \mathrm{ml}$ of strain A1 culture $(n=2)$ were applied for the cDNA synthesis. The qPCR analysis was conducted using Fast SYBR Green Master Mix with the 7500 Fast Real-Time PCR System (ABI) $(n=3)$ and the single-amplicon production in each reaction was confirmed by the dissociation curve. All the procedures for the qPCR were conducted following the manufacturer's instruction. The primer sequences targeting six analyzed genes are shown in Supplementary Table 5.

Gene and genome analyses. The open-reading frame (ORF) predictions and annotations for the assembled genomes and contigs were conducted using Migap (http://www.migap.org/index.php/en) ${ }^{64}$. The 16S rRNA gene sequences were aligned with cmalign (v1.1 $\mathrm{rcl}$ ) from the Infernal package and trimmed with TrimAl (v1.2rev59) for the phylogenetic tree construction ${ }^{16}$. The hydrogenase protein sequences were aligned with Muscle ${ }^{65}$. The trees were created by using maximum-likelihood with RaxML, and the robustness of furcated branches was supported by bootstrap values (100 replicates ${ }^{66}$ A BLAST Ring image generator was employed for visualizing a prokaryote genome as a circular image with multiple prokaryote genome comparisons ${ }^{67}$. GenomeMatcher was used for the comparisons of contigs with the 'compare sequence' mode ${ }^{68}$.

In silico DNA-DNA hybridization. The raw reads from strains A1, B1 and $\mathrm{H} 1$ sequencing (average read length $=101 \mathrm{bp}$ ) were mapped to each gap-closed or draft genome using CLC (Version 6.0.3). The cutoff parameters that we have attempted are 95 for the similarity cutoff while 70,80 and 90 for the length cutoff.

\section{References}

1. Sleep, N. H., Meibom, A., Fridriksson, T., Coleman, R. G. \& Bird, D. K. $\mathrm{H}_{2}$-rich fluids from serpentinization: geochemical and biotic implications. Proc. Natl Acad. Sci. USA 101, 12818-12823 (2004).

2. Frost, B. R. \& Beard, J. S. On silica activity and serpentinization. J. Petrol. 48, 1351-1368 (2007).

3. Morrill, P. L. et al. Geochemistry and geobiology of a present-day serpentinization site in California: The Cedars. Geochim. Cosmochim. Acta. 109, 222-240 (2013)

4. Szponar, N. et al. Geochemistry of a continental site of serpentinization, the Tablelands Ophiolite, Gros Morne National Park: A Mars analogue. Icarus 224, 286-296 (2013).

5. Fryer, P. Serpentinite mud volcanism: observations, processes, and implications. Ann. Rev. Marine Sci. 4, 345-373 (2012).

6. Kelley, D. S. et al. An off-axis hydrothermal vent field near the Mid-Atlantic Ridge at 30 degrees N. Nature 412, 145-149 (2001).

7. Mottl, M. J., Komor, S. C., Fryer, P. \& Moyer, C. L. Deep-slab fluids fuel extremophilic Archaea on a Mariana forearc serpentinite mud volcano: Ocean Drilling Program Leg 195. Geochem. Geophys. Geosyst. 4, 9009 (2003).

8. Barnes, I., Lamarche, Jr. V. C. \& Himmelberg, G. Geochemical evidence of present-day serpentinization. Science 156, 830-832 (1967).

9. Marques, J. M. et al. Origins of high $\mathrm{pH}$ mineral waters from ultramafic rocks Central Portugal. Appl. Geochem. 23, 3278-3289 (2008).

10. Hosgormez, H. Origin of the natural gas seep of Çirali (Chimera), Turkey: Site of the first Olympic fire. J. Asian Earth Sci. 30, 131-141 (2007).

11. Barnes, I. \& O’Neil, J. R. Presentday serpentinization in New Caledonia, Oman and Yugoslavia. Geochim. Cosmochim. Acta. 42, 144-145 (1978).

12. Cipolli, F., Gambardella, B., Marini, L., Ottonello, G. \& Zuccolini, M. V. Geochemistry of high-pH waters from serpentinites of the Gruppo di Voltri (Genova, Italy) and reaction path modeling of $\mathrm{CO} 2$ sequestration in serpentinite aquifers. Appl. Geochem. 19, 787-802 (2004).

13. Abrajano, T. A. et al. Geochemistry of reduced gas related to serpentinization of the Zambales Ophiolite, Philippines. Appl. Geochem. 5, 625-630 (1990).

14. Peltonen, P., Kontinen, A., Huhma, H. \& Kuronen, U. Outokumpu revisited: New mineral deposit model for the mantle peridotite-associated $\mathrm{Cu}-\mathrm{Co}-\mathrm{Zn}-\mathrm{Ni}$ Ag-Au sulphide deposits. Ore Geol. Rev. 33, 559-617 (2008). 
15. Coleman, R. G. in: Ophiolites Oceanic Crust: New Insights from Field Studies and the Ocean Drilling Program, Geological Society of America Special Paper 349 (eds Y. Dilek, E. Moores, D. Elthon, A. Nicolas) 351-364 (Geological Society of America, 2000).

16. Suzuki, S. et al. Microbial diversity in The Cedars, an ultrabasic, ultrareducing, and low salinity serpentinizing ecosystem. Proc. Natl Acad. Sci. USA 110, 15336-15341 (2013).

17. Tiago, I. \& Verissimo, A. Microbial and functional diversity of a subterrestrial high $\mathrm{pH}$ groundwater associated to serpentinization. Environ. Microbiol. 15, 1687-1706 (2013).

18. Brazelton, W. J., Morrill, P. L., Szponar, N. \& Schrenk, M. O. Bacterial communities associated with subsurface geochemical processes in continental serpentinite springs. Appl. Environ. Microb. 79, 3906-3916 (2013).

19. Daae, F. L. et al. Microbial life associated with low-temperature alteration of ultramafic rocks in the Leka ophiolite complex. Geobiology 11, 318-339 (2013).

20. Itavaara, M. et al. Characterization of bacterial diversity to a depth of $1500 \mathrm{~m}$ in the Outokumpu deep borehole, Fennoscandian Shield. FEMS. Microbiol. Ecol. 77, 295-309 (2011)

21. Willems, A. et al. Hydrogenophaga, a new genus of hydrogen-oxidizing bacteria that includes Hydrogenophaga flava comb. nov (formerly Pseudomonas flava), Hydrogenophaga palleronii (formerly Pseudomonas palleronii), Hydrogenophaga pseudoflava (formerly Pseudomonas pseudoflava and 'Pseudomonas carboxydoflava'), and Hydrogenophaga taeniospiralis (formerly Pseudomonas taeniospiralis). Int. J. Syst. Bacteriol. 39, 319-333 (1989).

22. Gan, H. M., Chew, T. H., Tay, Y. L., Lye, S. F. \& Yahya, A. Genome sequence of Hydrogenophaga sp strain PBC, a 4-aminobenzenesulfonate-degrading bacterium. J. Bacteriol. 194, 4759-4760 (2012).

23. Spring, S., Wagner, M., Schumann, P. \& Kampfer, P. Malikia granosa gen. nov., sp nov., a novel polyhydroxyalkanoate- and polyphosphate-accumulating bacterium isolated from activated sludge, and reclassification of Pseudomonas spinosa as Malikia spinosa comb. nov. Int. J. Syst. Evol. Microbiol. 55, 621-629 (2005).

24. Rivière, J. M. \& Schmidt, K. in The Prokaryotes. (eds Dworkin, M. et al.) Ch. 40 941-954 (Springer New York, 2006).

25. Williamson, A. J. et al. Microbial reduction of Fe(III) under alkaline conditions relevant to geological disposal. Appl. Environ. Microb. 79, 3320-3326 (2013).

26. Roadcap, G. S., Sanford, R. A., Jin, Q. S., Pardinas, J. R. \& Bethke, C. M. Extremely alkaline $(\mathrm{pH}>12)$ ground water hosts diverse microbial community. Ground Water 44, 511-517 (2006).

27. Fukuda, A. et al. Geomicrobiological properties of ultra-deep granitic groundwater from the Mizunami Underground Research Laboratory (MIU), central Japan. Microb. Ecol. 60, 214-225 (2010).

28. Davidson, M. M. et al. Capture of planktonic microbial diversity in fractures by long-term monitoring of Flowing Boreholes, Evander Basin, South Africa. Geomicrobiol. J. 28, 275-300 (2011).

29. Schrenk, M. O., Kelley, D. S., Bolton, S. A. \& Baross, J. A. Low archaeal diversity linked to subseafloor geochemical processes at the Lost City Hydrothermal Field, Mid-Atlantic Ridge. Environ. Microbiol. 6, 1086-1095 (2004).

30. Brazelton, W. J., Schrenk, M. O., Kelley, D. S. \& Baross, J. A. Methane- and sulfur-metabolizing microbial communities dominate the Lost City hydrothermal field ecosystem. Appl. Environ. Microbiol. 72, 6257-6270 (2006).

31. Takai, K. et al. Marinobacter alkaliphilus sp nov., a novel alkaliphilic bacterium isolated from subseafloor alkaline serpentine mud from Ocean Drilling Program Site 1200 at South Chamorro Seamount, Mariana Forearc. Extremophiles 9, 17-27 (2005)

32. Okland, I., Huang, S., Dahle, H., Thorseth, I. H. \& Pedersen, R. B. Low temperature alteration of serpentinized ultramafic rock and implications for microbial life. Chem. Geol. 318, 75-87 (2012).

33. Barnard, G. N. \& Sanders, J. K. The poly-beta-hydroxybutyrate granule in vivo. A new insight based on NMR spectroscopy of whole cells. J. Biol. Chem. 264, 3286-3291 (1989).

34. Sorokin, D. Y. Is there a limit for high-pH life? Int. J. Syst. Evol. Microbiol. 55, 1405-1406 (2005).

35. Brazelton, W. J., Nelson, B. \& Schrenk, M. O. Metagenomic evidence for $\mathrm{H}_{2}$ oxidation and $\mathrm{H}_{2}$ production by serpentinite-hosted subsurface microbial communities. Front. Microbiol. 2, 268 (2012).

36. Sorek, R., Kunin, V. \& Hugenholtz, P. CRISPR—a widespread system that provides acquired resistance against phages in bacteria and archaea. Nat. Rev. Microbiol. 6, 181-186 (2008).

37. Heinzinger, N. K., Fujimoto, S. Y., Clark, M. A., Moreno, M. S. \& Barrett, E. L. Sequence analysis of the phs operon in Salmonella typhimurium and the contribution of thiosulfate reduction to anaerobic energy metabolism. $J$. Bacteriol. 177, 2813-2820 (1995).

38. Vignais, P. M., Billoud, B. \& Meyer, J. Classification and phylogeny of hydrogenases. FEMS. Microbiol. Rev. 25, 455-501 (2001).

39. Vignais, P. M. \& Colbeau, A. Molecular biology of microbial hydrogenases. Curr. Issues Mol. Biol. 6, 159-188 (2004).
40. Shively, J. M., van Keulen, G. \& Meijer, W. G. Something from almost nothing: Carbon dioxide fixation in chemoautotrophs. Annu. Rev. Microbiol. 52, 191-230 (1998).

41. Shiba, H., Kawasumi, T., Igarashi, Y., Kodama, T. \& Minoda, Y. The $\mathrm{CO}_{2}$ assimilation via the reductive tricarboxylic acid cycle in an obligately autotrophic, aerobic hydrogen-oxidizing bacterium Hydrogenobacter thermophilus.. Arch. Microbiol. 141, 198-203 (1985).

42. Aoshima, M., Ishii, M. \& Igarashi, Y. A novel enzyme, citryl-CoA synthetase, catalysing the first step of the citrate cleavage reaction in Hydrogenobacter thermophilus TK-6. Mol. Microbiol. 52, 751-761 (2004).

43. Doukov, T. I., Iverson, T. M., Seravalli, J., Ragsdale, S. W. \& Drennan, C. L. A $\mathrm{Ni}-\mathrm{Fe}-\mathrm{Cu}$ center in a bifunctional carbon monoxide dehydrogenase/acetyl-CoA synthase. Science 298, 567-572 1075843 (2002).

44. Fukuzawa, H., Suzuki, E., Komukai, Y. \& Miyachi, S. A gene homologous to chloroplast carbonic-anhydrase (Icfa) is essential to photosynthetic carbondioxide fixation by Synechococcus Pcc7942. Proc. Natl Acad. Sci. USA 89, 4437-4441 (1992).

45. Ragsdale, S. W. Life with carbon monoxide. Crit. Rev. Biochem. Mol. Biol. 39, 165-195 (2004).

46. King, G. M. \& Weber, C. F. Distribution, diversity and ecology of aerobic COoxidizing bacteria. Nat. Rev. Microbiol. 5, 107-118 (2007).

47. Kang, B. S. \& Kim, Y. M. Cloning and molecular characterization of the genes for carbon monoxide dehydrogenase and localization of molybdopterin, flavin adenine dinucleotide, and iron-sulfur centers in the enzyme of Hydrogenophaga pseudoflava. J. Bacteriol. 181, 5581-5590 (1999).

48. Hicks, D. B., Liu, J., Fujisawa, M. \& Krulwich, T. A. F1F0-ATP synthases of alkaliphilic bacteria: lessons from their adaptations. Biochim. Biophys. ActaBioenerg 1797, 1362-1377 (2010).

49. Krulwich, T. A., Sachs, G. \& Padan, E. Molecular aspects of bacterial pH sensing and homeostasis. Nat. Rev. Microbiol. 9, 330-343 (2011).

50. Mulkidjanian, A. Y., Galperin, M. Y., Makarova, K. S., Wolf, Y. I. \& Koonin, E. V. Evolutionary primacy of sodium bioenergetics. Biol. Direct. 3, 13 (2008).

51. Blair, D. F. \& Berg, H. C. The MotA protein of E. coli is a proton-conducting component of the flagellar motor. Cell 60, 439-449 (1990).

52. Imae, Y. \& Atsumi, T. $\mathrm{Na}^{+}$-driven bacterial flagellar motors. J. Bioenerg. Biomembr. 21, 705-716 (1989)

53. Ezaki, T., Hashimoto, Y. \& Yabuuchi, E. Fluorometric deoxyribonucleic aciddeoxyribonucleic acid hybridization in microdilution wells as an alternative to membrane filter hybridization in which radioisotopes are used to determine genetic relatedness among bacterial strains. Int. J. Syst. Bacteriol. 39, 224-229 (1989).

54. Giovannoni, S. J. et al. Genome streamlining in a cosmopolitan oceanic bacterium. Science 309, 1242-1245 (2005).

55. Swan, B. K. et al. Prevalent genome streamlining and latitudinal divergence of planktonic bacteria in the surface ocean. Proc. Natl Acad. Sci. USA 110, 11463-11468 (2013)

56. Mira, A., Ochman, H. \& Moran, N. A. Deletional bias and the evolution of bacterial genomes. Trends Genet. 17, 589-596 (2001).

57. Vignais, P. M. \& Billoud, B. Occurrence, classification, and biological function of hydrogenases: an overview. Chem. Rev. 107, 4206-4272 (2007).

58. Preiss, L. et al. The c-ring stoichiometry of ATP synthase is adapted to cell physiological requirements of alkaliphilic Bacillus pseudofirmus OF4. Proc. Nat Acad. Sci. USA 110, 7874-7879 (2013).

59. Ishii, S. et al. Microbial population and functional dynamics associated with surface potential and carbon metabolism. ISME J. 8, 963-978 (2013).

60. Eck, G.-R.-V. Physiological and chemical tests for drinking water. NEN 1056 IV-2 Nederlandse Normalisatie Instituut Rijswijk, The Netherlands (1966).

61. Trüper, H. G. \& Schlegel, H. G. Sulphur metabolism in Thiorhodaceae I. Quantitative measurements on growing cells of Chromatium okenii. Antonie van Leeuwenhoek 30, 225-238 (1964).

62. Lovley, D. R. \& Phillips, E. J. Availability of ferric iron for microbial reduction in bottom sediments of the freshwater tidal potomac river. Appl. Environ. Microbiol. 52, 751-757 (1986).

63. Ishii, S. et al. A novel metatranscriptomic approach to identify gene expression dynamics during extracellular electron transfer. Nat. Commun. 4, 1601 (2013).

64. Sugawara, H., Ohyama, A., H, M. \& K, K. Microbial Genome Annotation Pipeline (MiGAP) for diverse users. 20th Int. Conf. Genome Informatics S-001, 1-2 (2009).

65. Edgar, R. C. MUSCLE: multiple sequence alignment with high accuracy and high throughput. Nucleic Acids Res. 32, 1792-1797 (2004).

66. Stamatakis, A. RAxML-VI-HPC: Maximum likelihood-based phylogenetic analyses with thousands of taxa and mixed models. Bioinformatics 22, 2688-2690 (2006).

67. Alikhan, N. F., Petty, N. K., Ben Zakour, N. L. \& Beatson, S. A. BLAST Ring Image Generator (BRIG): simple prokaryote genome comparisons. BMC Genomics 12, 402 (2011). 
68. Ohtsubo, Y., Ikeda-Ohtsubo, W., Nagata, Y. \& Tsuda, M. GenomeMatcher: A graphical user interface for DNA sequence comparison. BMC Bioinformatics $\mathbf{9}$, 376 (2008).

\section{Acknowledgements}

We greatly appreciate Roger Raiche and David McCrory for providing their private land for our research. We appreciate Orion Johnson, Nathan Walworth, Greg Wanger and Orianna Bretschger for the field supports and constructive discussions. We appreciate Yang Jiang for the conclusive identification of PHB. This work was funded by the NSFEAR Grant No 1024872. K.H.N., P.L.M. and G.M. were partly funded by the NASA Cooperative Agreement NNA13AA92A, NSERC Discovery Grant or ERC Advanced Grant No. 322551, respectively.

\section{Author contributions}

S.S. and J.G.K. designed research; S.S., J.G.K., K.S., S.V., A.W., D.Y.S. and X.Y.M. performed experiments; S.S., S.I., A.T. and G.M. performed in silico analysis; S.S., J.G.K., S.I., P.L.M, Y.K. and K.H.N. wrote the paper.

\section{Additional information}

Accession codes: The genomic sequences of strains Al and B1 have been deposited in the GenBank/EMBL/DDBJ nucleotide sequence databases under accession codes AP014568 (strain A1), AP014569 (chromosome of strain B1) and AP014570 (plasmid in strain B1). Contig sequences corresponding to the genome of strain $\mathrm{H} 1$ have been deposited in the GenBank/EMBL/DDBJ nucleotide sequence databases under accession codes BAWN01000001 to BAWN01000094.

Supplementary Information accompanies this paper at http://www.nature.com/ naturecommunications

Competing financial interests: The authors declare no competing financial interests.

Reprints and permission information is available online at http://npg.nature.com/ reprintsandpermissions/

How to cite this article: Suzuki, S. et al. Physiological and genomic features of highly alkaliphilic hydrogen-utilizing Betaproteobacteria from a continental serpentinizing site. Nat. Commun. 5:3900 doi: 10.1038/ncomms4900 (2014).

(c) (1) $\Theta$ This work is licensed under a Creative Commons Attribution(c) No No NonCommercial-NoDerivs 3.0 Unported License. The images or other third party material in this article are included in the article's Creative Commons license, unless indicated otherwise in the credit line; if the material is not included under the Creative Commons license, users will need to obtain permission from the license holder to reproduce the material. To view a copy of this license, visit http://creativecommons.org/licenses/by-nc-nd/3.0/ 